\title{
Особенности выделения нуклеиновых кислот из эфиромасличных растений
}

Браилко В.А.*, Булавин И.В., Гребенникова О.А., Митрофанова И.В.

Федеральное бюджетное учреждение науки «Ордена Трудового Красного Знамени Никитский ботанический сад -

Национальный научный центр РАН», Ялта, Россия

*e-mail: valentina.brailko@yandex.ru

Ключевые слова: эфиромасличные растения, ДНК, качество, спектрофотометрия, автоматический электрофорез

Цель: Для целей генотипирования и маркерной селекции эфиромасличных растений были подобраны и оптимизированы протоколы выделения ДНК, поскольку присутствие белков, полисахаридов и вторичных метаболитов, снижает эффективность ПЦР и качество библиотек для последующего секвенирования.

Oбъекты и методы: Работа выполнена на 10 сортах Rosa damascena Mill., 4 сортах Lavandula angustifolia Mill., 3 copтах Lavandula $\times$ intermedia Emeric. ex Loisel. и 4 сортах Thymus L. произрастающих в коллекции Никитского ботанического сада. Для выделения ДНК из молодых листьев использовали как коммерческие наборы, так и классический способ выделения (СТАВметод) и его модификации. Количество и качество ДНК определяли с помощью нанофотометра NanoPhotometer NP80 (Implen, Германия) и автоматической системы электрофореза Agilent 4200 TapeStation (Agilent Technologies, Германия).

Результаты: В тканях изученных растений включения с эфирными маслами (капли различного диаметра) находились в клетках мезофилла и железках, также обнаружены фенольные соединения. Качество всех образцов ДНК розы эфиромасличной, выделенных согласно протоколам коммерческих наборов было низким: $\mathrm{A}_{260 / 230}$ и $\mathrm{A}_{280 / 260}<1,30$, концентрация 52-146 нг/мкл. Для лаванды и лавандина количественный выход ДНК соответствовал указанным в протоколах значениям, соотношение $\mathrm{A}_{260 / 230}$ было $<1,80$. ДНК низкого качества получена с использованием автоматизированной системы подготовки проб (MagNA Pure LC 2.0, (Roche, Швейцария) с MagNA Pure Compact Nucleic Acid Isolation Kit I (Roche, Швейцария) и наборов DiamondDNA ${ }^{\mathrm{TM}}$ (DiamondDNA, Россия), PureLink ${ }^{\circledR}$ Plant Total DNA Purification Kit (Thermo Scientific ${ }^{\mathrm{TM}}$, СШA). Протоколы GeneJET Plant Genomic DNA Purification Kit (Thermo Scientific ${ }^{\mathrm{TM}}$, США) и NucleoSpin ${ }^{\circledR}$ Plant II Mini (Macherey-Nagel,Германия) позволили получить от 960 до 2800 нг ДНК из 100 мг ткани $\left(\mathrm{A}_{260 / 230}=1,65-1,80, \mathrm{~A}_{280 / 260}=1,03-1,96\right)$. Наилучшие результаты для всех исследованных растений получены при использовании СТАВ-метода и его модификаций (выход ДНК от 1,5 до 31,0 мг; $\mathrm{A}_{260 / 230,} \mathrm{~A}_{280 / 260}>1,9$; молекулярный размер от 42000 до >60 000 п.о.).

Bblвoдbl: Модифицирован и оптимизирован СТАВ-протокол выделения ДНК из ряда эфиромасличных растений, позволивший провести эффективную экстракцию ДНК из тканей исследуемых видов.

Благодарности: Работа выполнена в рамках Госзадания № 0829-2019-0038 ФГБУН «НБС-ННЦ» на базе УНУ «ФИТОБИОГЕН». 